\title{
Maize necrotic streak virus, a New Maize Virus with Similarity to Species of the Family Tombusviridae
}

Raymond Louie and M. G. Redinbaugh, USDA-ARS, Corn and Soybean Research, Department of Plant Pathology, The Ohio State University, Wooster 44691; D. T. Gordon, Department of Plant Pathology, The Ohio State University; and J. J. Abt and R. J. Anderson, USDA-ARS, Corn and Soybean Research, Department of Plant Pathology and Department of Entomology, The Ohio State University

\begin{abstract}
Louie, R., Redinbaugh, M. G., Gordon, D. T., Abt, J. J., and Anderson, R. J. 2000. Maize necrotic streak virus, a new maize virus with similarity to species of the family Tombusviridae. Plant Dis. 84:1133-1139.

A new virus was isolated from maize (Zea mays L.) leaves showing mild mosaic symptoms and coinfected with Maize dwarf mosaic virus. The virus was readily transmitted by vascular puncture inoculation (VPI) but not leaf-rub inoculation. Virus symptoms on susceptible maize included pale green, yellow, or cream-colored spots and streaks measuring 1 to $2 \mathrm{~mm}$ on emerging leaves 5 to 7 days post-VPI. As leaves developed, the spots and streaks became spindle-shaped, then coalesced into long, chlorotic bands. These bands became translucent and necrotic around the edges. There was a distinctive chlorosis on the stalks that became necrotic. Based on these distinctive symptoms, the new virus was named Maize necrotic streak virus (MNeSV). The virus was not transmitted by Aphis maidis-radicus, Myzus persicae, Macrosiphum euphorbiae, Rhopalosiphum padi, Dalbulus maidis, Graminella nigrifrons, Perigrinus maidis, or Diabrotica virgifera virgifera under persistent or nonpersistent conditions. Both susceptible and resistant maize genotypes were identified following VPI with MNeSV. The isolated virus had isometric $(32 \mathrm{~nm})$ virions and a single $29.5-\mathrm{kDa}$ coat protein. MNeSV was serologically distinct from morphologically similar maize viruses. The 4.3 -kb single-stranded RNA genome had 25 to $53 \%$ sequence identity with species in the family Tombusviridae.
\end{abstract}

Additional keywords: corn, virus disease

Outbreaks of some economically important maize virus diseases in the United States (e.g., diseases caused by the Maize dwarf mosaic virus [MDMV] and Maize chlorotic dwarf virus [MCDV] complex in the 1960s) appeared to be sudden and widespread. In contrast, Maize stripe virus

Corresponding author: M. G. Redinbaugh E-mail:redinbaugh.2@ osu.edu

The GenBank Accession number for the MNeSV sequence is AF266518.

This work is a cooperative investigation of the USDA-ARS, OSU, and OARDC, Wooster. Salaries and support provided by state and federal funds were appropriated to OSU-OARDC, Wooster.

Mention of a trademark, proprietary product, trade names or commercial products in this article is solely for the purpose of providing scientific information; it does not constitute a guarantee, warranty, recommendation, or endorsement by the USDA and does not imply approval to the exclusion of other products that also may be suitable.

Accepted for publication 28 June 2000.

Publication no. D-2000-0824-01R

This article is in the public domain and not copyrightable. It may be freely reprinted with customary crediting of the source. The American Phytopathological Society, 2000. and Maize chlorotic mottle virus (MCMV) have wide geographic ranges but tend to occur sporadically (8). Predicting the eventual spread or localization of maize virus disease is complicated by changes in crop traits or production practices that may inadvertently predispose maize to new or endemic pathogens that might have otherwise remained quiescent. Thus, whenever possible, it is advantageous to develop knowledge of new or endemic viruses infecting maize regardless of the disease's current economic impact. Accurate knowledge of virus properties and development of diagnostic tools allows us to monitor disease development and to develop appropriate control strategies in advance of epidemics.

An opportunity to study a virus disease of maize in advance of any economically important outbreaks occurred in June 1998 when field corn plants, thought to be infected with MCDV, were observed near Cochise, AZ. In 1 of 20 leaf samples sent to Ohio to be assayed for MCDV, a new maizeinfecting virus was identified and isolated. The virus was named Maize necrotic streak virus (MNeSV), based on the distinct symptoms it incited. The objectives of this study were to isolate, identify, and characterize this new virus. Preliminary studies of this virus were reported $(16,26)$.

\section{MATERIALS AND METHODS}

Pathogen transmission. Inoculum extracts were prepared by grinding leaf tissue in four volumes of $10 \mathrm{mM}$ potassium phosphate, pH 7 (buffer A). Initially, extracts were prepared from samples of fieldgrown maize leaves that showed mild mosaic symptoms, and tested for the presence of MCDV and MDMV by enzyme-linked immunosorbent assay (ELISA). One sample that showed an elevated, but statistically insignificant, reaction for MCDV in the ELISA was used as the initial inoculum source. Vascular puncture inoculation (VPI) was used to introduce the inoculum into 'Seneca Chief' sweet corn (15). Subsequently, leaves selected for making inoculum extracts were prepared from seedlings that had only high-contrast yellow, spindle-shaped streak symptoms, so that the pathogen could be separated from MDMV and other pathogens. This inoculum was tested to ensure the absence of MDMV by ELISA and by rub inoculation of MDMV-susceptible maize inbred Oh28. In addition, partially purified virion samples were examined for uniformity by electron microscopy. All subsequent experiments were done with this purified culture of MNeSV.

Mechanical transmission of MNeSV was tested by rubbing leaves of 14- to 20day-old maize inbred Oh28, Triticum aestivum 'Freedom' (single assay) and Sorghum bicolor 'Atlas' (four replicates) test plants between thumb and forefinger with inoculum mixed with 600-mesh silicon carbide and by VPI (15). For VPI, kernels were first soaked in tap water at $30^{\circ} \mathrm{C}$ for 2 $\mathrm{h}$, after which an engraving tool was used to push minuten pins through a $3-\mu l$ drop of inoculum placed on top of kernels. Inoculated kernels were planted into autoclaved greenhouse soil 2 days after VPI.

To test for soil transmission, 'Spirit' sweet corn was inoculated with MNeSV by VPI and kernels were planted into autoclaved greenhouse soil. After 14 to 70 days, the infected plants were cut off at soil level, and 5 Spirit sweet corn kernels were planted into each pot. Seedlings were observed for symptom expression for 35 to 51 days after planting.

Vector transmission. Vector transmission of MNeSV was tested with the corn root aphid Aphis maidis-radicus (Forbes), green peach aphid Myzus persicae (Sulzer), 
potato aphid Macrosiphum euphorbiae (Thomas), oat bird cherry aphid Rhopalosiphum padi L., corn leafhopper Dalbulus maidis (DeLong and Wolcott), blackfaced leafhopper Graminella nigrifrons (Forbes), corn planthopper Perigrinus maidis (Ashmead), and western rootworm Diabrotica virgifera virgifera (LeConte) adults under nonpersistent or persistent conditions. Test plants for vector transmission were 14- to 20-day-old maize inbred Oh28 or sweet corn (Seneca Chief or Spirit). Aphids (5 to 10 per plant) were used to inoculate 256 test plants, as described by Louie and Knoke (20). Briefly, aphids were given an acquisition access period (AAP) on infected source plants of 5 min after a starvation period of $60 \mathrm{~min}$ or 7 to 30 days for nonpersistent or persistent acquisition, respectively. An inoculation access period (IAP) of 1 or 2 days followed the AAP. Leafhoppers and planthoppers were given a 2- to 14-day AAP and an incubation period of up to 17 weeks, followed by an IAP of 7 days. Leafhoppers or planthoppers (3 to 35 per plant) were used to inoculate 827 test plants. Corn rootworms were given a 16-h to 5-day AAP and a 6-h to 5-day IAP. One to two adults per plant were used to inoculate 162 test plants. After the IAP, test plants were fumigated with Vapona for $2 \mathrm{~h}$ to remove insects, then observed for symptom development for 28 to 35 days.

Maize pathogen resistance. To test differences in virus susceptibility among maize genotypes, 20 kernels of each genotype were inoculated by VPI. Seedlings (5 plants per $10-\mathrm{cm}$ pot) were observed for symptoms over a 4-week period. Maize lines Longe 1, [MSRXPOOL9]C1F2-205-19(OSU23i)0-1-3-X (OSU23i) and Tzi4 were obtained from CIMMYT. These lines were previously found to be resistant to Maize streak virus (MSV; 2,3). Inbreds Oh28, Oh1VI, Pa405, and Va35 were from our stocks. Pa405 has resistance to MDMV, Wheat streak mosaic virus (WSMV) and Sugarcane mosaic virus (SCMV) $(13,14,17,23)$. Inbred Oh1VI is highly tolerant to MCDV infection (R. Louie, M. Jones, and R. J. Anderson, unpublished data). Pioneer hybrid 3379 (P3379), Spirit, and Seneca Chief were used as susceptible controls. The test was replicated three times. Differences among means were determined using a $t$ test.

Virus purification and characterization. The pathogen was purified using a modification of the MCDV purification protocol (21). Infected leaf laminar tissue was collected 25 to 30 days after VPI. The tissue $(60 \mathrm{~g})$ was ground in four volumes of buffer A containing $10 \mathrm{mM}$ dithiothreitol and filtered through four layers of cheesecloth. The filtrate was extracted twice with 0.2 volumes of chloroform and the aqueous phase was collected after centrifugation at $8,000 \times g$ for $15 \mathrm{~min}$ at $4^{\circ} \mathrm{C}$. The clarified aqueous phase was then cen- trifuged at $105,000 \times g$ for $4 \mathrm{~h}$ at $4^{\circ} \mathrm{C}$. The resulting pellet was resuspended in $0.8 \mathrm{ml}$ of buffer A. The suspension was diluted to $9.8 \mathrm{ml}$ with buffer A, brought to $3.2 \mathrm{M}$ $\mathrm{CsCl}$, and centrifuged at $183,000 \times g$ for $22 \mathrm{~h}$ at $10^{\circ} \mathrm{C}$. The resulting optically dense band was collected and diluted with six volumes of buffer A. Virus particles were collected by centrifugation at $135,000 \times g$ for $2 \mathrm{~h}$ at $4^{\circ} \mathrm{C}$. The resulting pellet was resuspended in $1 \mathrm{ml}$ of $25 \mathrm{mM}$ HEPES, $\mathrm{pH}$ 7.4, containing $0.1 \mathrm{M} \mathrm{NaCl}$ (HBS). Protein concentrations were determined using the dye binding method (25).

Purified virus samples were placed on 300-mesh formvar-coated copper grids and negatively stained using phosphotungstic acid at $\mathrm{pH}$ 7.3. Samples were viewed and photographed with a Philips $201 \mathrm{C}$ electron microscope at $80 \mathrm{kV}$.

Capsid protein molecular weight. Proteins were separated by sodium dodecyl sulfate-polyacrylamide gel electrophoresis (SDS-PAGE) on $12 \%$ Tris-HCl Ready Gels (BioRad, Richmond, CA) according to the "Ready Gels Application Guide" (Cat. \#161-0993). BioRad Broad Range Molecular Weight Markers were used as standards. After electrophoresis, the gels were silver stained (24). The analysis was repeated nine times.

Antibody and $F\left(a b^{\prime}\right)_{2}$ unit production. Two New Zealand rabbits were immunized with four injections of purified virus (1.0 $\mathrm{mg}$ of protein per injection) on days 0,13 , 37 , and 63 using a standard protocol (9). Antibody titers were determined using the $\left.\mathrm{F}(\mathrm{ab})^{\prime}\right)_{2}$-Protein A ELISA described below with 1:4 dilution of virus-infected leaf tissue extract and an antiserum twofold dilution series beginning at $1: 50$ to 1:51,200 for serum collected at 42, 52, 74, and 79 days following the first injection. Titers were 1:400, 1:100, 1:25,600, and $1: 12,800$ for the first rabbit, and 1:3,200, $1: 100,1: 51,200$, and $1: 12,800$ for the second rabbit (data not shown), indicating that the virus was satisfactorily immunogenic. $\mathrm{F}\left(\mathrm{ab} \mathrm{b}^{\prime}\right)_{2}$ fragments were produced from immunoglobulin $\mathrm{G}$, purified from antiserum collected on day 42, as previously described (22).

$\mathbf{F}\left(\mathbf{a b}^{\prime}\right)_{2}$-Protein A ELISA protocol. The protocol of Gingery and Nault (7) was followed with minor modifications. $\mathrm{F}\left(\mathrm{ab}^{\prime}\right)_{2}$ units were diluted to $1 \mu \mathrm{g} / \mathrm{ml}$ with $0.05 \mathrm{M}$ $\mathrm{NaHCO}_{3}$, pH 9.6, (coating buffer) and wells washed with $0.025 \mathrm{M}$ Tris, $\mathrm{pH}$ 8.0, containing $0.15 \mathrm{M} \mathrm{NaCl}$ and $0.05 \%$ polyethylene sorbitan monolaurate (TBS-T). Leaf tissue was ground in TBS-T (1:4 $\mathrm{wt} / \mathrm{vol}$ ) and centrifuged at $16,000 \times g$ for 3 min, after which the supernatant was used for ELISA.

Bound antigen was detected by addition of antibodies diluted in TBS-T plus $1 \%$ bovine serum albumin as indicated below, and added at $50 \mu \mathrm{l}$ per well. Plates were incubated for $2 \mathrm{~h}$ at room temperature and wells washed as above. Antisera were made against MNeSV $(1: 12,800)$, the M1 strain of MCDV (1:800), the severe isolate of MCDV (1:800), MCMV (1:800), Maize rayado fino virus (MRFV; 1:400), and Maize white line mosaic virus (MWLMV; 1:12,800). These antisera were produced prior to this study (D. T. Gordon, unpublished data).

The peroxidase substrate solution (120 $\mu \mathrm{l} /$ well) contained $7 \mathrm{mM} 3,3^{\prime}, 5,5^{\prime}$ tetramethyl benzidine and $1 \% \mathrm{H}_{2} \mathrm{O}_{2}$ in 10 $\mathrm{mM}$ sodium acetate, $\mathrm{pH} 5.8$, containing $1 \%$ dimethylsulfoxide. When the absorbance at $630 \mathrm{~nm}$ of the most intensely colored sample reached 3 , the reactions were stopped by adding $25 \mu \mathrm{l}$ of $3 \mathrm{M} \mathrm{H}_{2} \mathrm{SO}_{4}$. Subsequently, the absorbance of samples at 450 $\mathrm{nm}$ was determined.

Genome characterization. For determination of genome nucleic acid type and size, nucleic acids were extracted from purified virions after dilution with 4 volumes of $10 \mathrm{mM}$ Tris, $\mathrm{pH} \mathrm{8,} 1 \mathrm{mM}$ EDTA. The sample was extracted three times with phenol:chloroform:isoamyl alcohol (25:24:1 $\mathrm{vol} / \mathrm{vol} / \mathrm{vol})$, precipitated with sodium acetate/ethanol, and resuspended in water (29). The concentration of nucleic acid was determined from the absorbance at $260 \mathrm{~nm}$. Where indicated, $5 \mu \mathrm{g}$ of nucleic acid was treated with RNAse A (\#R5125, Sigma-Aldrich, St. Louis) or DNAse I (\#Z3100, Promega, Madison, WI) at 5 $\mathrm{ng} / \mu \mathrm{l}$ for $10 \mathrm{~min}$ prior to electrophoretic analysis. Total and double-stranded RNAs (dsRNA) were isolated from maize leaves as previously described $(4,32)$. RNA sizes were determined after electrophoresis on denaturing agarose gels stained with eithidium bromide $(27,29)$. Subsequently, RNAs were transferred to GeneScreen membranes (NEN Life Sciences, Boston) and probed with ${ }^{32} \mathrm{P}$-labeled DNA (27). Analyses were done at least twice and representative data are shown.

RNA was isolated from virions (purified through the first ultracentrifugation step) using the method of Chirgwin et al. (4). The isolated RNA was used for cDNA synthesis with the Superscript Choice System according to the manufacturer's instructions (Life Technologies, Grand Island, NY). The cDNAs were ligated into EcoRI-digested, phosphatase-treated pSPORT1, and transformed into Escherichia coli DH5 $\alpha$ cells (Life Technologies). For sequence analysis, two overlapping clones of 2.5 and $1.9 \mathrm{~kb}$ with homology to the $5^{\prime}$ and $3^{\prime}$ end of Tomato bushy stunt virus (TBSV), respectively, were chosen. Both strands of each clone were sequenced in 550- to 700-bp segments by primer walking using an $\mathrm{ABI}$ 3700 DNA Sequence Analyzer and Big Dye Terminator chemistry according to the supplier's instructions (PE Applied Biosystems, Foster City, CA).

The sequences were analyzed using MacVector (Oxford Molecular Group, Oxford, England) and assembled using As- 
semblyLIGN (Oxford Molecular Group). For virus genome comparison, sequences were aligned using the PILEUP function of the Wisconsin Sequence Analysis Package (Genetics Computer Group, Inc., Madison, WI). The $p$ distances were calculated for the aligned sequences, and the dendrogram was created with the neighbor-joining algorithm using MEGA (11).

\section{RESULTS}

The maize leaf samples sent from Arizona had only mild mosaic symptoms typical of MDMV infection when they arrived in Ohio. Subsequent ELISA tests confirmed the presence of MDMV in the samples, but did not detect MCDV (data not shown). Three samples, which had slightly higher but statistically insignificant ELISA readings when tested with MCDV antisera, were each bioassayed on 100 Seneca Chief kernels by VPI. The bioassay and subsequent ELISA indicated that two of the samples were infected with MDMV (data not shown). In addition, 3 of 69 kernels inoculated with sap from one of the MDMV-infected leaf samples developed pale, yellow-green streaks and spots on a green background suggestive of a second viral disease. Later, distinctive, high-contrast, yellow, spindle-shaped streaks with necrotic margins developed on the stalks and older leaves (data not shown). Apparently, this leaf sample was also asymptomatically infected with another pathogen. An MDMV-free culture was developed and used to characterize the properties of this new pathogen, MNeSV.

Symptomatology. Symptoms incited by the pure isolate of MNeSV were pale green or yellow to cream-colored spots and streaks, 1 to $2 \mathrm{~mm}$ long on the first emerging leaf of Spirit sweet corn, 5 to 7 days after VPI. As the four subsequent leaves developed, many of the spots and streaks became spindle-shaped and interspersed among healthy tissues. In subsequent developing leaves, the lamina generally became diseased, displaying long chlorotic bands. Many chlorotic bands coalesced and some became translucent and necrotic around the edges (Fig. 1). Most distinctive were the chlorotic streaks on the stalks that also became necrotic.

Pathogen transmission. MNeSV was not transmitted by leaf-rub inoculation to the maize inbred Oh28 in any of 29 attempts; nor was it transmitted to wheat or sorghum by rub inoculation. MNeSV was not transmitted by any of the four aphid or two leafhopper species tested, nor was it transmitted by the planthopper or beetle species used. When Spirit kernels were sown into pots of greenhouse soil that previously contained infected plants, 18 of $4,949(0.4 \%)$ of the newly emerged plants showed symptoms.

Pathogen resistance in maize. Significant differences were found among maize genotypes evaluated for resistance to

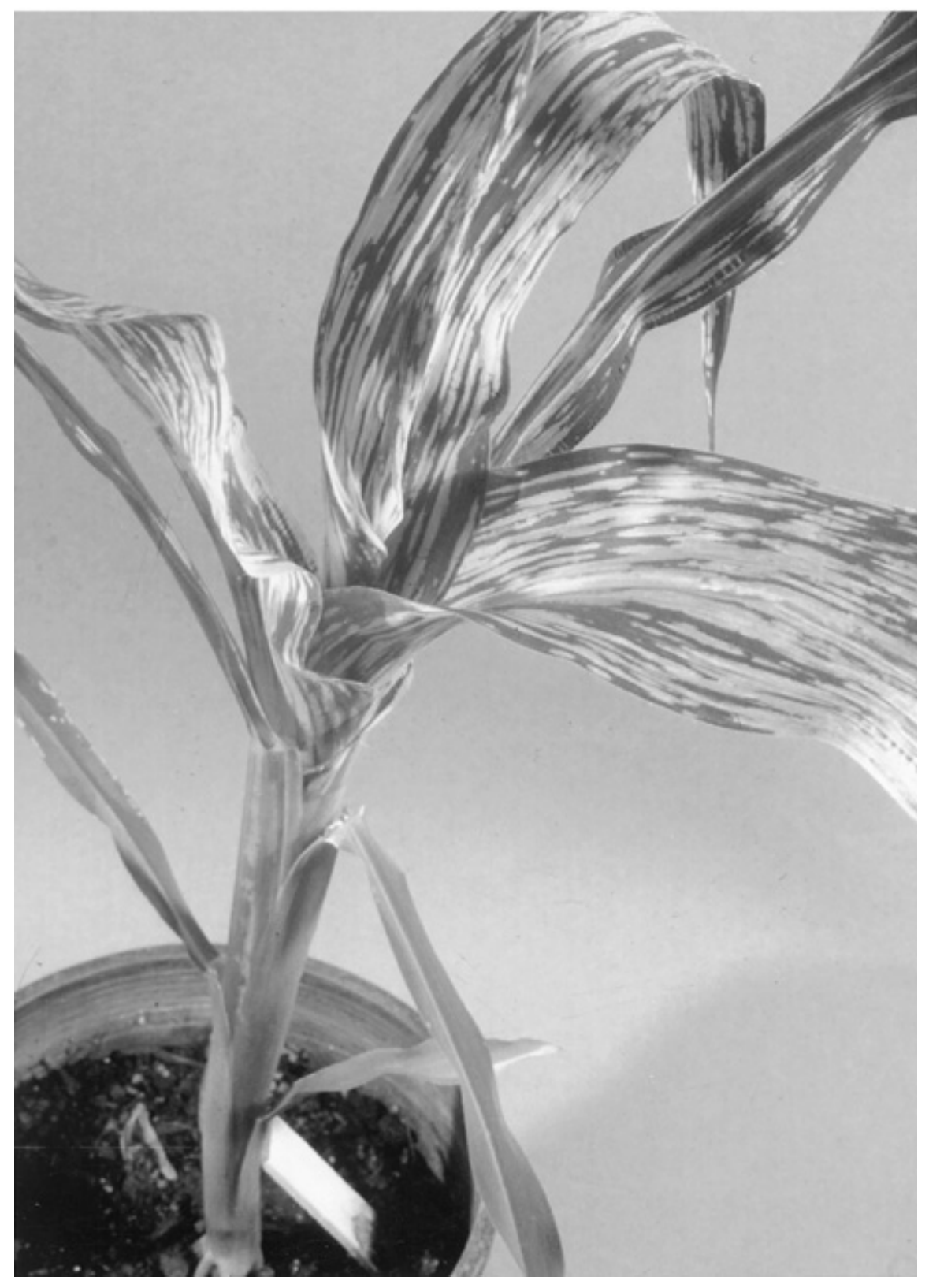

Fig. 1. Sweet corn cv. Spirit 25 days after vascular puncture inoculation with extracts from a purified Maize necrotic streak virus isolate.

Table 1. Response of maize inbreds and hybrids to inoculation with Maize necrotic streak virus

\begin{tabular}{llcc}
\hline Germ plasm & Virus resistance $^{\mathbf{w}}$ & ${\text { Infection }(\%)^{\mathbf{x}}}^{\mathbf{n}}$ & Severity $^{\mathbf{y}}$ \\
\hline Va35 & $\ldots$ & $44 \pm 3 \mathrm{a}$ & 4.9 \\
Spirit & $\ldots$ & $30 \pm 5 \mathrm{ab}$ & 4.2 \\
Tzi4 & MSV & $30 \pm 5 \mathrm{ab}$ & 4.9 \\
P3379 & $\ldots$ & $22 \pm 10 \mathrm{bc}$ & 3.8 \\
Pa405 & MDMV, WSMV, SCMV & $22 \pm 11 \mathrm{bc}$ & 2.4 \\
Oh28 & $\ldots$ & $21 \pm 7 \mathrm{bc}$ & 3.5 \\
Seneca Chief & $\ldots$ & $13 \pm 9 \mathrm{bcd}$ & 3.5 \\
Longe & MSV & $10 \pm 3 \mathrm{~cd}$ & 2.6 \\
Oh1VI & MCDV & $0 \mathrm{~d}$ & $\ldots$ \\
OSU23i & MSV & $0 \mathrm{~d}$ & $\ldots$ \\
\hline
\end{tabular}

${ }^{\mathrm{w}} \mathrm{MSV}=$ Maize streak virus, MDMV = Maize dwarf mosaic virus, $\mathrm{SCMV}=$ Sugarcane mosaic virus, WSMV = Wheat streak mosaic virus, MCDV = Maize chlorotic dwarf virus.

${ }^{x}$ Mean \pm SE for three replications. Means followed by different letters were significantly different $(P$ $<0.05)$.

y Severity rating was based on a scale of 0 (no symptoms) to 5 (severe chlorosis and necrosis).

${ }^{\mathrm{z}}$ [MSRXPOOL9]C1F2-205-19(OSU23i)0-1-3-X. 
MNeSV after VPI (Table 1). Transmission ranged from $45 \%$ infection of the inbred Va35 to $10 \%$ for Longe 1. No infection was seen in inbred Oh1VI, which carries two quantitative trait loci for tolerance to MCDV infection (R. Louie, M. Jones, and R. J. Anderson, unpublished data), or OSU23i, which has a high level of tolerance for MSV infection (3). In contrast, the WSMV-, MDMV- and SCMV-resistant Pa405 (13,14,17,23), and MSV-tolerant Tzi4 $(2,3,12)$ inbreds showed the same level of infection as two susceptible controls (P3379 and Oh28).

Virus purification and capsid protein characterization. A single optically dense band was evident after isobouyant centrifugation of extracts from symptomatic maize leaves, suggesting that a single en-

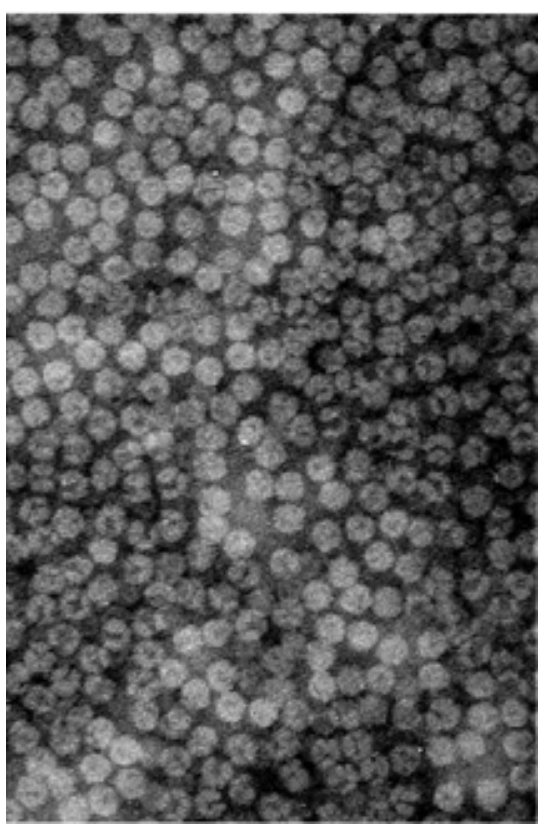

Fig. 2. Ultrastructural analysis of Maize necrotic streak virus. The bar represents $100 \mathrm{~nm}$.

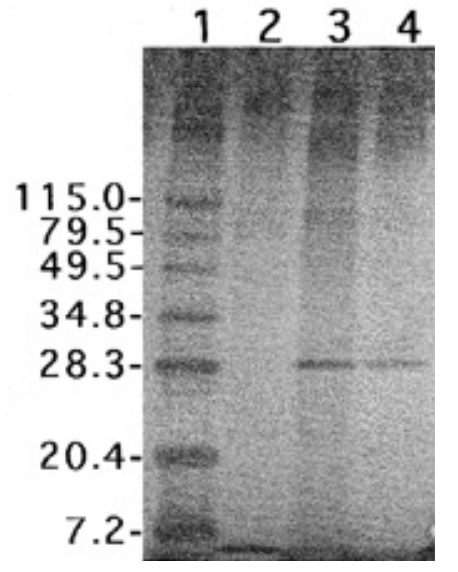

Fig. 3. Analysis of capsid protein molecular weight. Lane 1, standard proteins of indicated molecular mass; lane 2, the supernatant and lane 3, the pellet from the sucrose gradient centrifugation step; and lane 4 , the purified virus were analyzed. tity was present. In five independent isolations, the purification protocol yielded 70 to $110 \mathrm{mg}$ of viral protein per kilogram of leaf tissue. The purified virus preparation contained isometric particles of $32 \mathrm{~nm}$ (Fig. 2). A single protein band with a molecular mass of $29.5 \pm 0.3 \mathrm{kDa}$ (mean \pm standard error [SE], $n=9$ ) was observed in SDS-PAGE (Fig. 3, lane 4). This species was not among the proteins that did not sediment at $135,000 \times g$ from the clarified extract (Fig. 3, lane 2). Antiserum raised to $\mathrm{MNeSV}$ reacted specifically with a protein of about $29 \mathrm{kDa}$ in purified, infectious virus preparations and in extracts of infected leaves on Western blots, but not with proteins from healthy control leaves (data not shown).

Serology. The serological relationships among MNeSV and other maize-infecting viruses having small isometric particles that are known to occur in the United States were tested (Table 2). All previously developed antisera showed strong positive reactions with the homologous antigen and had mean absorbances less than twice that of the healthy control with nonhomologous antigens. Antiserum raised to MNeSV showed a high degree of reactivity to extracts from MNeSV-infected leaves, with an absorbance more than 45 times that of the healthy control. Although MWLMV and MCDV-M1 reacted more strongly with the MNeSV antisera than did the healthy control, their reactions were less than 15 and $10 \%$, respectively, of that for MNeSV. This data indicated that the MNeSV antiserum showed a high degree of specificity for the virus.

Viral genome characterization. The nucleic acid from purified MNeSV had an absorbance ratio $(260 / 280 \mathrm{~nm})$ of $1.86 \pm$ 0.16 (mean $\pm \mathrm{SE}, n=3$ ). The nucleic acid was sensitive to digestion with RNAse A but not DNAse (data not shown). The genomic RNA had a molecular size of 4.3 $\pm 0.1 \mathrm{~kb}$ (mean $\pm \mathrm{SE}, n=4$; Fig. $4 \mathrm{~A}$ ). No other RNA or DNA species was consistently observed in virion nucleic acid preparations. Four virus-specific dsRNAs were isolated from infected leaves. One corresponded to the genomic RNA with a molecular weight of about $4 \mathrm{~kb}$ (data not shown). A second species $(1.8 \mathrm{~kb})$ was observed in five of six samples and two $(1.7$ and $1.6 \mathrm{~kb})$ were observed in four of six samples. The viral RNA was a predominant species in total leaf RNA isolated from infected plants (Fig. 4B). The abundance of the RNA in plant leaves was similar to that observed for TBSV (30); however, subgenomic MNeSV RNAs were not detected on ethidium bromide-stained gels of leaf RNA.

Two overlapping cDNA clones were identified which spanned 3,907 nucleotides, or more than $90 \%$ of the MNeSV sequence based on a genomic RNA length of $4.3 \mathrm{~kb}$ (Fig. 5). The clone sequences encoded five open reading frames (ORFs; Fig. 5A). ORF 1 (nucleotides 95 to 895) encoded a protein of $33.3 \mathrm{kDa}$ with $51 \%$ identity with the p33 protein of TBSV. With read-through translation of an amber codon at nucleotides 896 to 898 , as previously observed in tombusviruses $(10,28)$, ORF 1 plus ORF 2 encoded a 92.1-kDa protein with 40 to $42 \%$ identity to the p92 replicase genes of tombusviruses. ORF 3 (nucleotides 2,492 to 3,262) encoded a 27.4-kDa protein, which had 44 and $37 \%$ sequence identity with the Tobacco necrosis virus (TNV) and Southern bean mosaic virus (SBMV) capsid protein genes, respectively. This portion of the genome was less similar ( $<30 \%$ identity) to TBSV. ORF 4 (nucleotides 3,301 to 3,837 ) encoded a 20.4-kDa protein with 70 to $75 \%$ identity with the p22 gene of tombusviruses. ORF 5 (nucleotides 3,333 to 3,905) encoded a 21.4-kDa protein with 44 to $48 \%$ identity to the 19 gene of tombusviruses.

The genomic RNA sequence of MNeSV was further compared with those of tombusviruses and other species of the family Tombusviridae, including Necro-, Diantho, Carmo- and Machlomovirus (Fig. 5B). In this analysis, MNeSV did not cluster with strongly supported clade containing the tombusviruses. However, it was more closely related to the tombusviruses than were other viruses in the family Tombus-

Table 2. Serological relationships between Maize necrotic streak virus (MNeSV) and other maize viruses with small isometric or geminate particles

\begin{tabular}{lcccccc}
\hline & \multicolumn{7}{c}{ Antiserum $^{\mathbf{y}}$} \\
\cline { 2 - 7 } Antigen $^{z}$ & MNeSV & MCDV-M1 & MCDV-T & MCMV & MRFV & MWLMV \\
\hline MNeSV & 1.37 & 0.10 & 0.05 & 0.04 & 0.03 & 0.04 \\
MCDV-M1 & 0.12 & 1.45 & NT & 0.03 & NT & 0.02 \\
MCDV-T & 0.03 & 0.04 & 0.95 & 0.05 & 0.07 & 0.01 \\
MCMV & 0.03 & NT & 0.06 & 0.87 & 0.08 & 0.01 \\
MRFV & 0.01 & NT & 0.08 & 0.03 & 0.78 & 0.01 \\
MWLMV & 0.20 & 0.06 & 0.08 & 0.07 & 0.07 & 1.11 \\
Control & 0.03 & 0.06 & 0.06 & 0.05 & 0.07 & 0.02 \\
\hline
\end{tabular}

y MCDV-M1 = Maize chlorotic dwarf virus $\mathrm{M} 1$ strain, $\mathrm{MCDV}-\mathrm{T}=$ Maize chlorotic dwarf virus type strain, MCMV = Maize chlorotic mottle virus, MRFV = Maize rayado fino virus, MWLMV = Maize white line mosaic virus, Control = leaf tissue from uninoculated plants. Values presented are the mean absorbance for two replicates minus the absorbance of the buffer control. NT $=$ not tested.

${ }^{\mathrm{z}}$ Antigen source: virus-infected lyophilized maize leaves (MCDV-T), fresh maize leaves (MNeSV, MCMV, MRFV, MWLMV, and healthy control), or fresh johnson grass leaves (MCDV-M1). 
viridae. Whereas the aligned tombusvirus sequences had 68 to $88 \%$ sequence identity, the MNeSV sequence had 52 to $53 \%$ identity with the tombusviruses. Both $\mathrm{MNeSV}$ and the tombusvirus group were 25 to $40 \%$ identical with the TNV, CRSV, CARMV, and MCMV sequences.

\section{DISCUSSION}

Laboratory tests are frequently used to confirm the identity of a plant pathogen initially diagnosed by symptoms in fieldgrown plants. In the present study, several different assays of maize plants thought to be infected with MCDV indicated that the plants were infected with two other viral pathogens, MDMV and a previously uncharacterized virus. The newly described virus, $\mathrm{MNeSV}$, was detected only after VPI of susceptible maize inbred with an extract from a field sample showing MDMV symptoms. The relative ease of MNeSV transmission by VPI facilitated separation of the virus from MDMV, and allowed for development of a pure culture of MNeSV.

Culture of $\mathrm{MNeSV}$ in the absence of other pathogens, and its transmission to maize by VPI and reisolation from infected maize showing characteristic disease symptoms through 18 successive generations, fulfilled Koch's Postulates. The symptomatology, ease of transmission by VPI, particle morphology, and single-stranded RNA (ssRNA) genome all indicated a viral pathogen. A distinctive symptom of the disease was the necrosis surrounding the long, spindle-shaped streaks in the latter stages of disease development, particularly on the stalks of seedling plants. These distinctive symptoms were the basis for the proposed name, Maize necrotic streak virus (MNeSV).
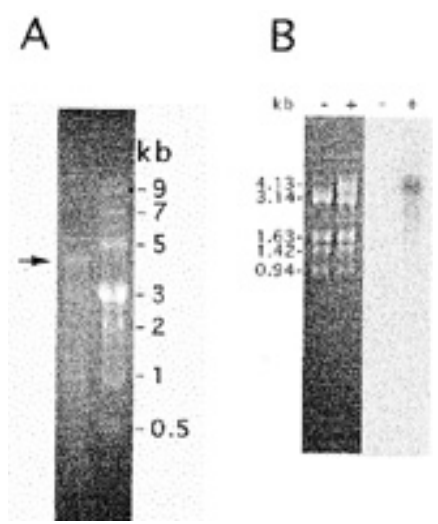

Fig. 4. Analysis of the pathogen RNA. (A) Lane 1, RNA isolated from purified virions and lane 2, an RNA ladder with standards of indicated length were electrophoresed on a denaturing agarose gel and stained with ethidium bromide. The arrow indicates the position of the viral genomic RNA. (B) Total RNA isolated from healthy (-) and pathogen-infected (+) maize leaves stained with eithidium bromide (left panel). Subsequently, the RNA was transferred to a membrane and probed with a cDNA corresponding to nucleotides 1,597 to 2,372 of MNeSV (right panel). Molecular sizes of the plant are shown at the left of the figure.
Although MNeSV was distinct from any known plant virus, it shared several characteristics with viruses of the genus Tombusvirus (28). Both MNeSV and the tombusviruses had small isometric particles and single-stranded, positive-sense RNA genomes with sizes of 4 to $5 \mathrm{~kb}$. Neither was transmitted by the usual viral vectors, but both were soil transmitted (28). The most striking similarity between MNeSV and the tombusviruses was the comparable arrangement of the genes and ORFs within their genomes $(10,28)$. Both genomes encoded 5 ORFs that included a 30 - to 33$\mathrm{kDa}$ protein at the $5^{\prime}$ end of the genome. In both viruses, ORF 1 was separated from ORF 2 by an amber codon, and readthrough translation ORF 1 plus ORF 2 yielded a 92-kDa protein with homology to RNA-dependent RNA polymerases. As in TBSV, the MNeSV ORF 3 encoded a putative capsid protein. Finally, ORF 4 and ORF 5 overlapped and were read in different frames in both tombusviruses and MNeSV. While carmo-, necro-, machlomoand dianthoviruses also had many similarities to the tombusviruses $(10,28)$, no other viral genus had the gene arrangement of $\mathrm{MNeSV}$ and the tombusviruses.

Although MNeSV had clear similarities to the tombusviruses, it was distinct from this genus in several ways. In particular,
MNeSV was not transmitted by rub-inoculation. Further, the MNeSV capsid protein $(29.5 \mathrm{kDa})$ was significantly smaller than those of tombusviruses, which have a 41-kDa capsid protein (28). In addition, the MNeSV capsid protein was more similar to those of necro- and sobemoviruses in size and sequence (28). Importantly, the MNeSV genome had 52 to $53 \%$ nucleotide identity with species in the genus Tombusvirus, whereas members of the genus shared 68 to $88 \%$ identity. Although the identical gene structure indicated a high degree of relationship between $\mathrm{MNeSV}$ and the tombusviruses, the lower sequence similarity suggested that MNeSV was not a member of the same genus.

Of the small isometric ssRNA viruses that infect maize, MNeSV was clearly distinguished from MRFV and MCMV serologically and by genomic sequence. Although MNeSV antiserum reacted weakly with MCDV-M1, this virus was shown to have three distinct capsid proteins with molecular weights of 23 to 34 $\mathrm{kDa}$ and was transmitted by leafhoppers (7). These data, coupled with the lack of reactivity of MNeSV with the MCDV-M1 antiserum, indicated that there was not likely to be any close relationship between the two viruses. The MNeSV antiserum reacted with a single polypeptide on West-

A:

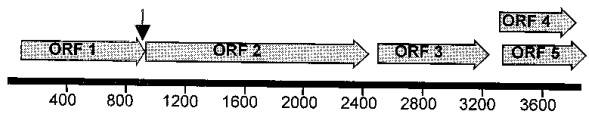

B:

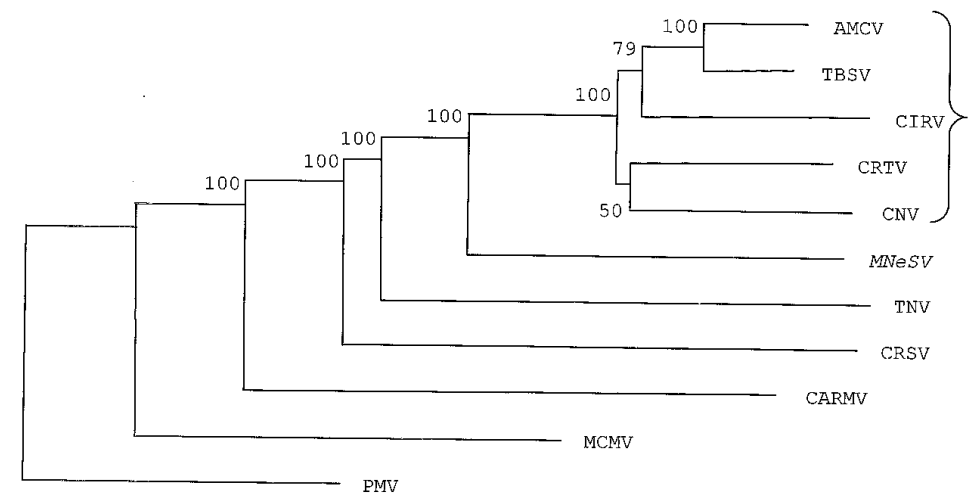

Fig. 5. Genomic sequence analysis of Maize necrotic streak virus (MNeSV) and comparison with species of the family Tombusviridae. MNeSV sequence (GenBank Accession number AF266518) was determined as described. (A) Five open reading frames (ORFs) predicted by the 3,907-bp sequence of two overlapping cDNA clones included ORF 1 (nucleotides 95 to 2458), ORF 2 (nucleotides 2,492 to 3,262), ORF 3 (nucleotides 3,301 to 3,837), and ORF 4 (nucleotides 3,333 to 3,905). The downward arrow indicates the position of an amber (TAG) stop codon (nucleotides 896 to 898). (B) Comparison of MNeSV sequence with those for species of the family Tombusviridae obtained from GenBank. The numbers at the nodes represent bootstrap confidence levels for 500 replicates. The tombusviruses are noted with a bracket. The species examined and their GenBank accession numbers included Artichoke mottle crinkle virus (AMCV, X62493); Tomato bushy stunt virus (TBSV, M21958); Carnation Italian ringspot virus (CIRV, X85215), Cymbidium ringspot virus (CRTV, X15511); Cucumber necrosis virus (CNV, M25270); Tobacco necrosis virus (TNV, D00942); Carnation ringspot virus (CRSV, L18870); Carnation mottle virus (CARMV, X02986); and Maize chlorotic mottle virus (MCMV, X14736). Panicum mosaic virus (PMV, U55002) was included as the selected outgroup. 
ern blot analyses (data not shown); therefore, it was unlikely that the purified $\mathrm{MNeSV}$ preparations used for antiserum preparation were contaminated with MCDV. Thus, the weak reaction of MCDV-M1 with the MNeSV antiserum was likely to be spurious.

The MNeSV antiserum also reacted weakly with MWLMV. This virus shared several characteristics with MNeSV, including inefficient soil transmission, a small isometric particle, and an ssRNA genome $(1,6,18)$. A high virus titer for these viruses was indicated by isolation of 70 to 100 and 200 to $400 \mathrm{mg}$ of viral protein per kilogram of infected leaf material for MNeSV and MWLMV, respectively (6). Further, neither virus was transmitted by leaf-rub inoculation. The MWLMV single capsid protein $(32 \mathrm{kDa})$ and ssRNA genome $(3.7 \mathrm{~kb})$ sizes were fairly close to those found for MNeSV (6). However, MWLMV has been reported in France, Italy, and the northeastern and Great Lakes regions of the United States (18), but it has not been reported to occur in Arizona. Unfortunately, no information about the MWLMV genome sequence was available. There was a recent report of another maize-infecting virus from Africa, Maize mild mottle virus (MMMV), with similarity to viruses in the family Tombusvirideae (31). Given the similarities among MNeSV, MWLMV, and MMMV, a comparison of genome sequences for these three viruses would be of interest.

As expected, maize inbreds and hybrids had a differential response to MNeSV inoculation. Some maize genotypes were highly susceptible to MNeSV infection, while others appeared to be highly resistant. Interestingly, the most susceptible maize line identified in this study (Va35) was also highly susceptible to infection by several other virus diseases, including MCDV (R. Louie, M. Jones, and R. J. Anderson, unpublished data). In addition, the two highly resistant lines, Oh1VI and OSU23i, were highly tolerant of MCDV and MSV infection, respectively. Whether resistance genes for $\mathrm{MNeSV}, \mathrm{MCDV}$, or MSV cluster in maize similarly to other disease resistance genes (5) remains to be determined.

Although MNeSV developed high titer and caused severe disease in maize after VPI, there has been no report of similar symptoms occurring in field corn. The sample from which MNeSV was isolated was collected from a plant that was symptomless in the field. Symptoms associated with MNeSV infection were not observed on field corn near the site where the sample was collected in 1998 or 1999 (M. Nelson, personal communication). There are several possibilities that might explain the absence of disease symptoms. In the field, soil-transmitted viruses may remain localized in root tissues, and produce no obvious symptoms in aboveground organs
$(19,28)$. In addition, lack of transmissibility by arthropods and inefficient soil transmission as found in this study could limit virus spread. Alternatively, an as yet unidentified vector may not be widespread in the corn-growing area where the sample was collected. Finally, resistance to $\mathrm{MNeSV}$ was found in maize germ plasm; therefore, corn hybrids used in this area may be resistant to the virus. Speculation as to the source of the virus is difficult, given that no virus disease symptoms have been observed in the field. However, the area where the samples were collected was heavily infested with johnson grass (Sorghum halpense; M. Nelson, personal communication), a demonstrated source for several maize viruses, including MDMV and MCDV (8).

Although no agronomically important disease was associated with MNeSV, related virus species in the family Tombusviridae are characterized by wide host ranges, associations with a number of different vectors and transmission pathways, and significant economic losses. The identification of new or emerging maize viruses before they become economically important provides an opportunity to devise control measures in advance of need. The identification of resistant maize inbreds and development of assay tools for $\mathrm{MNeSV}$ in this study should allow us to respond quickly and appropriately to any future outbreak of this disease.

\section{ACKNOWLEDGMENTS}

We thank M. Nelson, University of Arizona, for supplying the leaf tissue from which MNeSV was isolated; K. J. Willie, J. D. Vacha, J. C. M. Todd, and D. E. Fulton for invaluable technical assistance; and E. M. Kretzschmar, R. E. Whitmoyer, and T. Meulia of the OARDC Molecular and Cellular Imaging Center for providing timely technical assistance, assistance with digital photographic reproduction, and sequence analyses, respectively.

\section{LITERATURE CITED}

1. Boothroyd, C. W., and Israel, H. W. 1980. A new mosaic disease of corn. Plant Dis. 64:218-219.

2. Brewbaker, J. L., Kim, S. K., and Logrono, M. L. 1991. Resistance of tropical maize inbreds to major virus and virus-like diseases. Maydica 36:257-265.

3. Changa, C. 1998. Susceptibility of resistant maize germplasm to maize streak geminivirus by vascular puncture inoculation. Ph.D. dissertation. The Ohio State University, Columbus.

4. Chirgwin, J. M., Arzybyla, A. E., MacDonald, R. J., and Rutter, W. J. 1979. Isolation of biologically active RNA from sources enriched in ribonuclease. Biochemistry 18:5294-5299.

5. Collins, N. C., Webb, C. A., Seah, S., Ellis, J. G., Hulbert, S. H., and Pryor, A. 1998. The isolation and mapping of disease resistance gene analogs in maize. Mol. Plant-Microbe Interact. 11:968-978.

6. de Zoeten, G. A., Arny, D. C., Grau, C. R., Saad, S. M., and Gaard, G. 1980. Properties of the nucleoprotein associated with maize white line mosaic in Wisconsin. Phytopathology 70:1019-1022.
7. Gingery, R. E., and Nault, L. R. 1990. Severe maize chlorotic dwarf disease caused by double infection with mild virus strains. Phytopathology 80:687-691.

8. Gordon, D. T, Bradfute, 0. E., Gingery, R. E., Knoke, J. K., Louie, R., Nault, L. R., and Scott G. E. 1981. Introduction: History, geographical distribution, pathogen characteristics, and economic importance. Pages 1-12 in: Virus and Virus-like Diseases of Maize in the United States. D. T. Gordon, J. K. Knoke, and G. E. Scott, eds. South. Coop. Ser. Bull. 247.

9. Harlow, E., and Lane, D. 1988. Antibodies: A Laboratory Manual. Cold Spring Harbor Laboratory, Cold Spring Harbor, NY.

10. Hearne, P. Q., Knorr, D. A., Hillman, B. I., and Morris, T. J. 1990. The complete genome structure and synthesis of infectious RNA from clones of tomato bushy stunt virus. Virology 177:141-151.

11. Kumar, S., Tamura, K., and Nei, M. 1993 MEGA: Molecular Evolution and Genetic Analysis, vers. 1.0. The Pennsylvania State University, University Park.

12. Kyetere, D. T., Ming, R., McMullen, M. D., Pratt, R. C., Brewbaker, J., and Musket, T. 1998. Genetic analysis of tolerance to maize streak virus in maize. Genome 42:20-26.

13. Lei, J. D., and Agrios, G. M. 1986. Mechanisms of resistance in corn and maize dwarf mosaic virus. Phytopathology 76:1034-1040.

14. Louie, R. 1986. Effects of genotype and inoculation protocols on resistance evaluation of maize to maize dwarf mosaic virus strains. Phytopathology 76:769-773.

15. Louie, R. 1995. Vascular puncture of maize kernels for the mechanical transmission of maize white line mosaic virus and other viruses of maize. Phytopathology 85:139-143.

16. Louie, R., Abt, J., Redinbaugh, M. G., Gordon, D. T., and Bradfute, O. E. 1999. Isolation of a new maize virus. Ohio J. Sci. 99:A-24.

17. Louie, R., and Darrah, L. L. 1980. Disease resistance and yield loss to sugarcane mosaic virus in East African-adapted maize. Crop Sci. 20:638-640.

18. Louie, R., Gordon, D. T., Knoke, J. K., Gingery, R. E., Bradfute, O. E., and Lipps, P. E. 1982. Maize white line mosaic virus in Ohio. Plant Dis. 66:167-170.

19. Louie, R., Gordon, D. T., Madden, L. V., and Knoke, J. K. 1983. Symptomless infection and incidence of maize white line mosaic virus. Plant Dis. 67:371-373.

20. Louie, R., and Knoke, J. K. 1975. Strains of maize dwarf mosaic virus. Plant Dis. Rep. 59:518-522.

21. Louie, R., Knoke, J. K., and Gordon, D. T. 1974. Epiphytotics of maize dwarf mosaic and maize chlorotic dwarf diseases in Ohio. Phytopathology 64:1455-1459.

22. McDaniel, L. L., and Gordon, D. T. 1989. Characterization of the oat-infecting strain of maize dwarf mosaic virus. Phytopathology 79:113-120.

23. McMullen, M. D., and Louie, R. 1991. Identification of a gene for resistance to wheat streak mosaic virus in maize. Phytopathology 81:624-627.

24. Merril, C. R., Goldman, D., and Van Keuren, M. L. 1983. Simplified silver protein detection and image enhancement methods in polyacrylamide gels. Electrophoresis 3:17-23.

25. Redinbaugh, M. G., and Campbell, W. H. 1985. Adaptation of the dye-binding protein assay to microtiter plates. Anal. Biochem. $147: 144-147$

26. Redinbaugh, M. G., Louie, R., Gordon, D. T., Abt, J. J., and Anderson, R. J. 1999. Maize necrotic streak, a new virus with sequence homology to tombusviruses. (Abstr.) Phytopathology 89:S65.

27. Redinbaugh, M. G., Wadsworth, G. J., and 
Scandalios, J. G. 1988. Characterization of catalase transcripts and their differential expression in maize. Biochem. Biophys. Acta 951:104-116.

28. Russo, M., Burgyan, J., and Martelli, G. P. 1994. Molecular biology of the Tombusviridae. Adv. Virus Res. 44, 381-428.

29. Sambrook, J., Fritsch, E. F., and Maniatis, T.
1989. Molecular Cloning: A Laboratory Manual. Cold Spring Harbor Laboratory Press, Cold Spring Harbor, NY.

30. Scholthof, H. B., and Jackson, A. O. 1997. The enigma of pX: a host-dependent cis-acting element with variable effects on tombusvirus RNA accumulation. Virology 237:5665
31. Thottappilly, G., Qiu, W. P., Batten, J. S., Hughes, J. N., and Scholthof, K.-B. J. 1999. A new virus on Maize in Nigeria: Maize Mild Mottle Virus. Plant Dis. 83:302.

32. Valverde, R. A., Nameth, S. T., and Jordan, R. L. 1990. Analysis of double-stranded RNA for plant virus diagnosis. Plant Dis. 74:255258. 